\title{
BIBLIOGRAFIE PRACÍ PETRA SVOBODNÉHO
}

Bibliografie je řazena chronologicky, první část tvoří skupina studií, článků, recenzí a zpráv. V této skupině jsou předřazeny $\mathrm{v}$ jednotlivých letech studie před drobnějšími popularizačními články, recenzemi a zprávami o literatuře. Druhá část je soupisem editorské a redakční činnosti. V záznamech je uvedeno jméno Petra Svobodného v př́ípadě, kdy není jediným autorem textu.

\section{2}

[Virtanen, Keijo: Settlement or Return: Finnish Emigrants (1860-1930) in the International Overseas Return Migrations Movement]. Československý časopis historický 80, 1982, č. 4, s. 626-627. ISSN 0045-6187.

[Černyševa, O. V.: Švecija v gody vtoroj mirovoj vojny]. Československý časopis historický 80, 1982, č. 3, s. 467-468. ISSN 0045-6187.

\section{3}

[Skandinavskij sbornik]. Československý časopis historický 81, 1983, č. 3, s. 464. ISSN 0045-6187.

\section{4}

Renesanční humanismus v Čechách a na Moravě. Společenské vědy ve škole 40, 1983/1984, č. 2, s. 41-45. ISSN 0231-5289.

1000 let Švédska - od asů k Vasům. Muzejní a vlastivédná práce 22, 1984, č. 2, s. 110-111. ISSN 0027-5255.

\section{5}

[Hlaváčková, L. - Rozsívalová, E.: Studium a přednášky na lékařské fakultě pražské univerzity v letech 1690-1848]. Časopis lékařu českých 124, 1985, č. 10, s. 317. ISSN 0008-7335.

Nová literatura o klášteře Ostrov u Davle (okr. Praha-západ). Památky středních Čech 1, 1985, s. 170-172. ISSN 0862-1586.

\section{6}

Sociální a regionální struktura literárně činných absolventů pražské univerzity v letech 1500-1620. AUC-HUCP 26, 1986, fasc. 1, s. 7-36. ISSN 0323-0562.

Aeskulap a múza hudby. Zdravotnické noviny 35, 1986, č. 51-52, s. 11. ISSN 0044-1996. 
[Beiträge zur Hochschul- und Wissenschaftsgeschichte Erfurts, vormals: Beiträge zur Geschichte der Universität Erfurt (1392-1816). Bd. 20.]. Ludmila Hlaváčková, Petr Svobodný. AUC-HUCP 26, 1986, fasc. 1, s. 127-128. ISSN 0323-0562.

Jeden z knížat vědy [August von Wasserman]. Zdravotnické noviny 35, 1986, č. 19, s. 12. ISSN 0044-1996.

Vyznával lásku k dětem [Karel Švehla]. Zdravotnické noviny 35, 1986, č. 31, s. 12. ISSN 0044-1996.

\section{7}

Vlašský špitál na Malé Straně a jeho místo v péči o matku a dítě do josefínských reforem (1602-1789). Documenta Pragensia 7, 1987, s. 113-134. ISSN 0231-7443.

Pod severskou hvězdou. [Axel Munthe]. Zdravotnické noviny 36, 1987, č. 31, s. 12. ISSN 0044-1996.

[K. Trošev, Čeští lékaři v Bulharsku v době balkánských válek]. Praktický lékar̆ 67, 1987, č. 20, s. 763. ISSN 0032-6739.

Zdravotnická problematika historické Prahy. Praktický lékař 67, 1987, č. 5, s. 193. ISSN 0032-6739.

\section{8}

Biografický slovník pražské lékařské fakulty 1348-1939. Díl 1., A-K. Karel Beránek a kol. Praha: Univerzita Karlova, 1988. 296 s. [Petr Svobodný spoluautor hesel části 1883-1939, s. 136-296].

Inventář Vlašského špitálu na Malé Straně z roku 1789. Documenta Pragensia 8, 1988, s. 35-57. ISSN 0231-7443.

Přehled dějin výuky biologických věd na pražské lékařské fakultě. Ludmila Hlaváčková, Jana Nosáková, Petr Svobodný. AUC-HUCP 27, 1987 [vyd. 1988], fasc. 2, s. 21-53. ISSN 0323-0562

XVII. mikulovské sympózium J. E. Purkyně a jeho doba. Praktický lékař 68, 1988, s. 266. ISSN 0032-6739.

[Beiträge zur Hochschul- und Wissenschaftsgeschichte Erfurts. Bd. 21]. Ludmila Hlaváčková, Petr Svobodný. AUC-HUCP 28, 1988, fasc. 2, s. 83-84. ISSN 0323-0562

O zachování dobrého zdraví. Zdravotnické noviny 37, 1988, č. 1, s. 12. ISSN 0044-1996. 
Publikace Archivu UK vydané k purkyňovskému výročí. Praktický lékař 68, 1988, s. 269. ISSN 0032-6739.

Vlašský špitál na Malé Straně 1602-1789. Časopis lékařư českých 127, 1988, č. 5, s. 153-155. ISSN 0008-7335.

[Zarubežnaja istoriografija slavjanovedenija i balkanistiki]. AUC-HUCP 27, 1987 [vyd. 1988], fasc. 2, s. 125-126. ISSN 0323-0562.

\section{9}

Jan Jesenský - Jessenius. Přemožitelé času. Sestavil a redigoval Milan Codr. [Roč. 3], 1989 , č. 15 , s. $45-48$.

Mikuláš Klaudián. Zdravotnické noviny 38, 1989, č. 47, s. 12. ISSN 0044-1996.

[M. Veselý - L. Hlaváčková: Fakultní nemocnice v Praze-Motole.] Časopis lékařù českých 128, 1989, s. 462. ISSN 0008-7335.

\section{0}

Dějiny všeobecné nemocnice v Praze 1790-1952: (k 200. výročí založení nemocnice). Ludmila Hlaváčková, Petr Svobodný. Praha: Karolinum, 1990. 194 s., obr. příl. ISBN 80-7066-390-1. [Petr Svobodný: s. 137-165].

Dvě publikace k dějinám klinik české lékařské fakulty. [Sto let I. chirurgické kliniky FVL UK; Vencovský, Eugen: 100 let české psychiatrické kliniky v Praze 1886-1986)]. AUC-HUCP 30, 1990, fasc. 2, s. 118-120. ISSN 0323-0562.

\section{1}

Les enfants abandonnées de l'Hôpital italien de Prague. In: Enfance abandonnée et société en Europe, XIVe-XXe siècle. Actes du colloque international de Rome 30 et 31 janvier 1987). Rome: École Française de Rome, 1991, s. 1097-1102. Publications de l'Ecole française de Rome; 140. ISBN 2-7283-0217-0.

Matriky zemřelých Vlašského špitálu v Praze. Petr Svobodný, Jiří Kuděla. Historická demografie 15, 1991, s. 47-75. ISSN 0323-0937.

Pražská lékařská fakulta a populační problematika ČSR ve 20.-40. letech. Demografie 33, 1991, č. 3, s. 230-237. ISSN 0011-8265.

3. konference Československé komise pro dokumenty vědy a techniky. Znojmo, 23.-25. ř́ijna 1990. Časopis lékařủ českých 130, 1991, č. 20-21, s. 618-619. ISSN 0008-7335.

Dvě stě let Všeobecné nemocnice v Praze. Ludmila Hlaváčková, Petr Svobodný. Časopis lékařu českých 130, 1991, č. 20/21, s. 618-619. ISSN 0008-7335. 


\section{2}

Lékaři v životě a díle Bohuslava Balbína. In: Bohuslav Balbín a kultura jeho doby v Čechách: sborník z konference Památníku písemnictví. Ed. Zuzana Pokorná, Martin Svatoš. Praha: Památník národního písemnictví, 1992, s. 248-255. ISBN 3-412-04991-3.

Vlašský špitál a anatomické pitvy na pražské lékařské fakultě v 60. a 70. letech 18. století. Časopis lékařu českých 131, 1992, č. 5, s. 152-153. ISSN 0008-7335.

Umění léčit. Dějiny a současnost 14, 1992, č. 3, s. 64.[Gaming, květen-ř́ijen 1991]. ISSN 0418-5129.

Univerzitní budovy: sci-fi, nebo „bestia triumhans“? Tvar 3, 1992, č. 2, s. 3. ISSN 0862-657X.

Das welsche Spital an der Kleinseite und seine Stellung in der Mutter- und Kind-Fürsorge vor den Josephinischen Reformen (1602-1789). In: Historia hospitalium 18 (1989-1992), s. 79-91. ISSN 0440-9043.

\section{3}

Biografický slovník pražské lékařské fakulty 1348-1939. Díl 2. L-Ž. Uspořádali Ludmila Hlaváčková, Petr Svobodný. Autorský kolektiv Karel Beránek, Ludmila Hlaváčková, Jana Nosáková, Eva Rozsívalová, Petr Svobodný. Praha: Karolinum, 1993. 412 s. ISBN 80-7066-696-X. [1883-1939 Od zahájení činnosti české lékařské fakulty do zavření českých vysokých škol nacisty, s. 141-385, Jana Nosáková - Petr Svobodný].

Čeští lékaři - mecenáši České akademie věd a umění. In: Česká akademie věd a uměni 1891-1991: sborník príspěvki̊ k 100. výroči zahájení činnosti. Uspoř. Jiří Pokorný, red. Jan Novotný. Praha: Historický ústav AV ČR, 1993, s. 141-145. Práce Historického ústavu ČAV. Řada C - Miscellanea; sv. 8. ISBN 80-85268-29-9.

Dějiny pražských lékařských fakult 1348-1990. Ludmila Hlaváčková, Petr Svobodný. Praha: Karolinum, 1993. 151 s. ISBN 80-7066-742-7.

Učitelé české lékařské fakulty v zahraničí (1883-1948). Dějiny věd a techniky 26, 1993, č. 2, s. 109-112. ISSN 0300-4414.

Eva Rozsívalová - 70 let. Časopis lékař̃o českých 132, 1993, č. 5, s. 153. ISSN 0008-7335.

Z nedávné historie „univerzitních“ nemocnic v Praze. Puls 4, 1992-1993, č. 1, s. 10-11.

\section{4}

Child Mortality in the Italian Hospital in Prague (1719-1789). Journal of Family History 19, 1994, Nr. 2, s. 117-129. ISSN 0363-1990. 
Český národní komitét historiků. Tvar 5, 1994, č. 16, s. 3. ISSN 0862-657X.

Čeští lékaři v Bosně a Hercegovině. Dějiny a současnost 16, 1994, č. 3, s. 14-15. ISSN 0418-5129.

Důsledky 17. listopadu 1939 pro české lékařské fakulty. Časopis lékařu českých 133, 1994, č. 8, s. 245-248. ISSN 0008-7335.

Pražské lékařské sponze. In: Medzinárodné sympózium k dejinám mediciny a farmácie: zborník príspevkov z vedeckého sympózia 8.-10. júna vo Vysokých Tatrách. Ed. Milan Beniak. Bratislava: Ústav zdravotnej výchovy Spoločnost' sociálneho lekárstva SLS, 1994, s. 79-80. ISBN 80-7159-0055-X.

\section{5}

Déjiny Univerzity Karlovy I. 1347/48-1622. Redaktor svazku Michal Svatoš. [Autoři] Ivana Čornejová, Jaroslav Kadlec, Jiří Kejřr, Jiří Pešek, Michal Svatoš, Petr Svobodný a František Šmahel. Praha: Karolinum, 1992. 151 s. [Dějiny pražských lékařských fakult 1348-1990, s. 183-202]. ISBN 80-7066-968-3.

Isidor Soyka - Pettenkoferův žák. Dějiny vědy a techniky 28, 1995, č. 1, s. 1-14. ISSN 0300-4414.

Isidor Soyka - zakladatel Hygienického ústavu německé lékařské fakulty v Praze (druhé pražské období Isidora Soyky, 1884-1889). Dějiny vědy a techniky 28, 1995, č. 3, s. 145-166. ISSN 0300-4414.

Isidor Soyka - Gründer der Hygiene-Institutes an der deutschen Medizinischen Fakultät in Prag. In: Hygiene und Judentum. Nora Goldenbogen (Hrsg.) Dresden: Verein für Regionale Geschichte und Politik, 1995, s. 27-30. Historische Blätter. Sonderheft.

Jubilejní oslavy Vlašské kongregace a špitálu 1773. Documenta Pragensia 12, 1995, s. 159-164. ISSN 0231-7443.

„Nejmilejší doktor Marek, vir maximus“. Jan Marek Marci, lékař a fyziolog. In: Jan Marek Marci 1595-1667: život, dílo, doba. Lanškroun: Rosa, 1995, s. 43-57. ISBN 80-902087-0-3.

Od konce republiky k prvním měsícům protektorátu: přelomové roky ve svědectví presidiálních spisů okresních úřadů Praha-venkov Jílové. In: Pocta Evě Šmilauerové: sborník k 60. narozeninám PhDr. Evy Šmilauerové, CSc. Praha: Státní okresní archiv Praha-západ, 1995, s. 151-163.

Die Prager Hygiene-Schule: Edmund Weil und andere im Dienste der Wissenschafts Verstorbene. O. Klein, P. Svobodný. In: Hygiene und Judentum. Nora Goldenbogen (Hrsg.) Dresden: Verein für Regionale Geschichte und Politik, 1995, s. 23-26. Historische Blätter. Sonderheft. 
Prague University Registers and the Computer. In: The Art of Communication. Proceedings of the Eight International Conference of the Association for History and Computing, Graz, Austria, 24.-27. 1993. Ed. by Gerhard Jarizt... Graz: Akad. Dr. u. Verl.-Anst., 1995, s. 475-480. Grazer grundwissenschaftliche Forschungen; 1. ISBN 3-201-01646-2.

The Professionalisation of Czech Physicians, 1848-1939. In: Professionen in modernen Osteuropa. Hrsg. von Charles McClelland, Stephan Merl, Hannes Siegrist. Berlin: Duncker u. Humblot, 1995, s. 145-167. Giessener Abhandlugen zur Agrar- und Wirtschaftsforschung des europäischen Ostens; Bd. 207. ISBN 3-418-08444-6.

Česká lékařská věda v letech 1918-1938. Medica revue 2, 1995, č. 12, s. 29-30. ISSN 1210-9673.

Čeští lékaři ve společnosti přelomu 19. a 20. století. Medica revue 2, 1995, č. 10, s. 27-28. ISSN 1210-9673.

Dějiny a (počítačová) současnost. Dějiny a současnost 17, 1995, č. 1, s. 58-59. ISSN 0418-5129.

Financování vědecké práce lékařu za první republiky. Zdravotnické noviny 44, 1995, č. 51-52. Lékařské listy s. 13. ISSN 0044-1996.

Historie morových epidemií. Vesmír 74, 1995, č. 9, s. 496-503. ISSN 1210-9673.

[Kronika medicíny]. Dějiny a současnost 17, 1995, č. 1, s. 58-60. ISSN 0418-5129.

Křest’anský Euklidés, český Platón, pražský Hippokratés: Jan Marek Marci z Kronlandu (1595-1667). Dějiny a současnost 17, 1995, č. 5, s. 34-38. ISSN 0418-5129.

Nobelova cena za fyziologii a lékařství 1994. Časopis lékařu českých 134, 1995, č. 13, s. 415-417. ISSN 0008-7335.

Péče o zdraví za první Československé republiky. Medica revue 2, 1995, č. 11, s. 28-29. ISSN 1210-9673.

\section{6}

A Biographical Dictionary of Medical Faculties in Prague and its Processing on Computer. In: Computing Techniques and the History of Universities. Ed. Peter Denley. St. Katharinen: Max-Planck-Institut für Geschichte - Scripta Mercaturae Verlag, 1996, s. 176-181. Halbgraue Reihe zur historischen Fachinformatik, A 30. ISBN 3-89590-014-1.

Dějiny Univerzity Karlovy II, 1622-1802. Karel Beránek, Ivana Čornejová, Zdeněk Hojda, Ludmila Hlaváčková, Marie Pavlíková, Petr Svobodný. Redaktor svazku Ivana Čornejová. Praha: Karolinum, 1996. 285 s. [Lékařská fakulta, s. 165-202, Petr Svobodný - Ludmila Hlaváčková]. ISBN 80-7184-050-5. 
Lékaři v českých zemích 1848-1939. In: Profesionalizace akademických povolání v českých zemích v 19. a prvni polovině 20. století. Uspořádali Jan Havránek, Petr Svobodný. Praha: Karolinum, 1996, s. 126-146. ISBN 80-7184-081-5.

Způsoby financování vědecké práce v lékařských oborech (1918-1938). In: Postátňování, profesionalizace a mecenášství ve vědě českých zemí 1860-1945. Ed. Jan Janko. Praha: Institut základů vzdělanosti, 1996, s. 65-70. Studie z dějin techniky 2, 1996. ISSN 0862-3171.

[Benjamin Kuras: Czechs and Balances: - a Nation's Survival Kit.] Dějiny a současnost 18, 1996, č. 5, s. 60. ISSN 0418-5129.

Bibliografie publikovaných vědeckých prací Ludmily Hlaváčkové (1961-1994). AUC-HUCP 35, 1995 [vyd. 1996], fasc. 1-2, s. 123-127. ISSN 0323-0562.

[J. Boříková: Sen života a bouře skutečnosti, vyprávěné O. Kutvirtovi, profesoru UK.] In: Minulostí Západočeského kraje. Sv. 31. Ústí nad Labem: 1996, s. 286-289. ISBN 80-901761-9-4.

Dryáčníci, mastičkáři, kati, lazebníci, ranhojiči, chirurgové... Dějiny výuky medicíny a zdravotnické výchovy v českých zemích. Zdravotnické noviny 45, 1996, č. 12, s. 11. ISSN 0044-1996.

Historie středověkých špitálů a klášterní medicíny. Zdravotnické noviny 45, 1996, č. 7, s. 6. ISSN 0044-1996.

Jan Jesenius (1566-1621). Sborník lékařský 97, 1996, č. 3, s. 441-443, ISSN 0036-5327.

Kolaborace, přizpůsobení nebo odboj? Medica Revue 3, 1996, č. 1, s. 30-31. ISSN 1210-9673.

Kruh se uzavírá. Medica Revue 1996, č. 4, s. 37-38. ISSN 1210-9673.

Lékařská věda a výuka v poválečném Československu. Medica Revue 3, 1996, č. 3, s. 39-40. ISSN 1210-9673.

Lékařské fakulty v ČSR a za protektorátu (1918 až 1945). Ludmila Hlaváčková, Petr Svobodný. Zdravotnické noviny 45, 1996, č. 38, s. 11. ISSN 0044-1996.

Lékařské školy na Moravě v 18. a 19. století. Ludmila Hlaváčková, Petr Svobodný. Zdravotnické noviny 45, 1996, č. 27, s. 11. ISSN 0044-1996.

Lékařky v českých zemích v první polovině 20. století. AUC-HUCP 35, 1995 [vyd. 1996], fasc. 1-2, s. 75-87. ISSN 0323-0562. 
Ludmila Hlaváčková a její „stůl k hostině připravený“. Eva Rozsívalová, Jana Nosáková, Petr Svobodný. AUC-HUCP 35, 1995 [vyd. 1996], fasc. 1-2, s. 9-10. ISSN 0323-0562.

50 let mimopražských fakult UK. Dějiny vědy a techniky 29, 1996, č. 3, s. 185-186. ISSN 0300-4414.

Pražská lékařská fakulta od obnovení po Bílé hoře do josefínských reforem (v letech 1623-1780. Zdravotnické noviny 45, 1996, č. 11, s. 11. ISSN 0044-1996.

Pražské lékařské fakulty v letech 1883 až 1918. Ludmila Hlaváčková, Petr Svobodný. Zdravotnické noviny 45, 1996, č. 38, s. 11. ISSN 0044-1996.

Pražské lékařské sponze. Dějiny a současnost 18, 1996, č. 3, s. 2-6. ISSN 0418-5129.

Působení učitelů Lékařské fakulty Pražské německé univerzity v zahraničí (1883-1945). Petr Svobodný, Ludmila Hlaváčková. In: 3. česko-slovenské sympozium k dějinám medicíny, farmacie a veterinární mediciny s mezinárodní účastí. Praha: Univerzita Karlova, 1. Lékařská fakulta, Ústav dějin lékařství, 1996, s. 89.

Studium lékařu před založením Univerzity Karlovy. Zdravotnické noviny 45, 1996, č. 8, Lékařské listy, s. 10. ISSN 0044-1996.

Studium lékařů od založení Univerzity Karlovy do Bílé hory (1348-1620). Zdravotnické noviny 45, 1996, č. 10, s. 4. ISSN 0044-1996.

Úcta k učiteli lékařského umění - imperativ Hippokratovy př́sahy. Zdravotnické noviny 45, 1996, č. 12, s. 11. ISSN 0044-1996.

Vlašský špitál na Malé Straně a výchova porodnosti. Zdravotnické noviny 45, 1996, č. 20, s. 15. ISSN 0044-1996.

Výchova ošetřovatelek a porodních babiček do roku 1948. Ludmila Hlaváčková, Petr Svobodný. Zdravotnické noviny 45, 1996, č. 38, s. 11. ISSN 0044-1996.

Z dějin nejstarší lékařské fakulty. Forum 3, 1996, č. 3, 1996, s. 13. ISSN 1211-1724.

Zdravotnictví a zdravotníci po roce 1945. Medica Revue 3, 1996, č. 2, s. 37-38.

1997

Contacts between Bohemian and Hungarian Medical Faculties (14th-20th Centuries). In: Universitas Budensis 1395-1995: International Conference for the History of Universities on the Occasion of the 600th Anniversary of the Foundation of the University of Buda. Ed. by László Szögi, Júlia Varga. Budapest: 1997, s. 251-260. ISBN 963-463-171-1. 
Edward Babák, Gerhard Domagk, Sigmund Freund, Tadeáš Hájek z Hájku, Ivan Honl, Josef Charvát, Rudolf Jedlička, Edward Jenner, Johannes Jessenius, Arnold Jirásek, Křišt’an z Prachatic, Vilém Laufberger, Marek Marci z Kronlandu, Zdeněk Mysliveček, Jan Evangelista Purkyně, Albert Schweizer, Josef Thomayer, Rudolf Virchow, Vladimír Vondráček, Zalužanský ze Zalužan. In: Listy: kdo? co? kdy? kde? proč? 6: Lékaři. Autorem souboru Miroslava Lavičková, Petr Svobodný, Pavel Drábek, Jindřich Bečvár. Praha: Encyklopedický dům, 1997, (Encyklopedická edice), list 3, 7, 12, 15, 19, 20, 22, 23, 24, 25, 27, 28, $31,33,40,42,44,46,47,48$. ISBN 80-86044-06-8.

Čas a 3. LF UK. Forum 4, 1997, č. 4, s. 7. ISSN 1211-1724.

Výročí vědy a techniky v roce 1997. P. Drápal, J. Folta, P. Svobodný, Z. Tempír. In: Dějiny vědy a techniky 3. Praha: Národní technické muzeum, 1997, s. 131-134. Rozpravy Národního technického muzea; 145.

Výuka medicíny v Československu po roce 1945. Zdravotnické noviny 46, 1997, č. 4, s. 15. ISSN 0044-1996.

\section{8}

Biographisches Lexikon der deutschen medizinischen Fakultät in Prag 1883-1945. Ludmila Hlaváčková, Petr Svobodný. Praha: Karolinum, 1998. 239 s. ISBN 80-7184-521-3.

Dějiny Univerzity Karlovy IV, 1918-1990. Jindřich Bečvář, Břetislav Fajkus, Jan Havránek, Jan Janko, Jan Jirák, Barbara Köpplová, Miroslav Kunštát, Alen Mišková, Jiří Pešek, Josef Petráň, Zdeněk Pousta, Václav Rusek, Petr Svobodný, Valentin Urfus, Marek Waic, Blanka Zilynská; redaktoři svazku Jan Havránek, Zdeněk Pousta. Praha: Karolinum, 1998. 671 s. [Lékařská fakulta, s. 93-119; Lékařská fakulta [Německá univerzita], s. 200-205; Lékařské fakulty v letech 1945-1990, s. 389-418; Farmaceutická fakulta se sídlem v Hradci Králové, s. 419-429, Václav Rusek - Petr Svobodný]. ISBN80-7184-539-6.

Generální raport o asijské choleře v Praze, Vídni a Mnichově: pozitivní stránky cholerových epidemií ve středoevropských metropolích 19. století. Ludmila Hlaváčková, Petr Svobodný. In: Ponížení a odstrčení. Města versus katastrofy: sborník příspěvků z 8. vědeckého zasedání Archivu hlavního města Prahy, konaného ve dnech 2. a 3. řijna 1990 a z 13. vědeckého zasedání Archivu hlavního města Prahy, uspořádaného ve spolupráci s Ost- und Südosteuropa Institut Wien - Aussenstelle Brno ve dnech 3. a 4. ř́jna 1995. Uspoř. Jiří Pešek a Václav Ledvinka. Praha: Scriptorium, 1998, s. 257-264. Documenta Pragensia; vol. 16. ISBN 80-86197-02-6.

Kniha o Praze I: Hradčany, Malá Strana, Staré Město, Nové Město, Židovské Město. Editor Pavel Augusta. Praha: MILPO, 1998. 215 s. [Vlašský špitál, s. 56-57; Cesta ke vzdělání, s. 138-145]. ISBN 80-86098-09-5.

„Most Beloved Doctor Marcus, Vir Maximus“: Joannes Marcus Marci - Physician and Physiologist. In: Joannes Marcus Marci: a seventeenth-century Bohemian Polymath. Edited by Petr Svobodný. Praha: Karolinum, 1998, s. 69-101. ISBN 80-7184-475-6. 
Universitas - civitas - sanitas: Relevante Quellen im Archiv der Karlsuniversität in Prag. In: Sozialgeschichte der Medizin. Hrsg. Sonia Horn, Susanne Claudine Pils. Wien München: Thaur, 1998, s. 52-56.Wiener Gespräche zur Sozialgeschichte der Medizin; Bd. 2. ISBN 3-85400-081-2.

Vznik a vývoj novoměstského nemocničního centra od konce 18. století do současnosti. Ludmila Hlaváčková, Petr Svobodný. In: Nové Město pražské ve 14.-20. století: sbornik referátů a diskusnich př́spěvků ze 16. zasedáni Archivu hlavního města Prahy a Ost- und Südosteuropa Institut Wien - Aussenstelle Brno u př́ležitosti 650. výročni založení Nového Města pražského ve dnech 31. března - 2. dubna 1998 v Novoměstské radnici. Praha: Scriptorium, 1998, s. 243-259. Documenta Pragensia; 17. ISBN 80-86197-06-9.

České lékařské fakulty po 17. listopadu 1939. Diagnóza 1, 1998, č. 1, s. 14. ISSN 1212-3595.

Grandseigneur Rudolf Jedlička (1869-1926). Forum 5, 1998, č. 1, s. 11. ISSN 1211-1724.

Pražská univerzita v evropském kontextu. Dějiny a současnost 20, 1998, č. 3, s. 53-54. ISSN 0418-5129.

Pražská univerzitní medicína byla v sedmnáctém století na evropské úrovni. Mladá fronta DNES. Př́loha Praha DNES 9, 1998, 13. 3. 1998, s. 2. ISSN 1210-1168.

Reformy zdravotnictví. Reflex 9, 1998, č. 50, s. 76-78. ISSN 0862-6634.

Šest a půl století výuky medicíny v Praze. Ludmila Hlaváčková, Petr Svobodný. Časopis lékařri českých 137, 1998, č. 7, s. 195-198. ISSN 0008-7335.

Věda v českých zemích za druhé světové války. Petr Svobodný, Blanka Zilynská. Dějiny a současnost 20,1998 , č. 1, s. 54-56. ISSN 0418-5129.

Věda v Československu 1945-1953. Forum 5, 1998, č. 6, s. 6. ISSN 1211-1724.

\section{9}

1888: Reformy zdravotnictví. In: Osudové osmičky. Petr Čornej, Jiří Pokorný. Praha: Nakladatelství Lidové noviny, 1999, s. 264-271. ISBN 80-106-322-3.

The German Medical Faculty in Prague in the International Network (1918-1938). In: L'enseignement des Elites en Europe Centrale: (19-20e siècles). Victor Karady, Mariusz Kulczykowski. Cracovie: Université Jagellonne, 1999, s. 175-191. ISBN 83-7188-268-8.

Otakar Eugen (Ignác) Schulz. In: Österreichisches biographisches Lexikon 1815-1950. Bd. 11. Wien: Verlag der Österreichischen Akademie der Wissenschaften, 1999, s. 350-351. ISBN 3-7001-2803-7. 
Pražské špitály a nemocnice. Petr Svobodný, Ludmila Hlaváčková. Praha: Nakladatelství Lidové noviny, 1999. 179 s. Knižnice Dějin a současnosti; sv. 8. ISBN 80-7106-315-0.

Kniha o Praze 6. Editor Pavel Augusta. Praha: MILPO, 1999. 192 s. [Nemocnice. Ludmila Hlaváčková, Petr Svobodný, s. 100-101]. ISBN 80-86098-11-7.

Lékařky v českých zemích v první polovině 20. století. Zdravotnické noviny. 48, 1999, č. 13. Př́loha Lékařské listy 13, 1999, s. 15. ISSN 0044-1996.

„Nová německá medicína“ na německé univerzitě v letech 1939 až 1945. Zdravotnické noviny 48, 1999, č. 34, s. 8-9. ISSN 0044-1996.

O některých věcech raději mlčím... Josef Charvát (1897-1984). Forum 6, 1999, č. 3, s. 9. ISSN 1211-1724.

Otec české neurologie Kamil Henner. Forum, 6, 1999, 5, č. 9, s. 9. ISSN 1211-1724.

Tisíc let benediktinského kláštera sv. Jana Křtitele na Ostrově u Davle. Dějiny a současnost 21, 1999, č. 6, s. 54.

\section{0}

Archives of Medical Faculties in the Czech Republic. In: Beiträge zur Geschichte und Entwicklung der mitteleuropäischen Universitätsarchive. Internationale Konferenz der mitteleuropäischen Universitätsarchive 06-09. Dezember 1999. Hrsg. von László Szögi. Budapest: Universitätsarchiv und Bibliothek der Eötvös Loránd Universität, 2000, s. 53-58. ISBN 963-463-428-1.

Němečtí komisaři pro českou lékařskou fakultu po 17. listopadu 1939. In: II. setkání archivárư vysokých škol ČR. Brno: Veterinární a farmaceutická univerzita, 2000, s. 52-64. ISBN 80-7305-385-3.

Stručné dějiny České onkologické společnosti. Pavel Klener, Ludmila Hlaváčková, Petr Svobodný. Praha: Galén, 2000. 70 s. Almanach medicíny; sv. 4. ISBN 80-7262-083-5.

Únor 1948 na lékařských fakultách UK očima pamětníků. In: História mediciny, farmácie a veterinárnej medicíny v kontexte vývoja európskej vedy 20. storočia. Ed. L. Pavlíková, M. Beniak. Bratislava: Juga, 2000, s. 189-192. ISBN 80-85506-99-8.

XIX. Mezinárodní kongres historických věd. Zpravodaj Historického klubu 11, 2000, č. 1, s. 32-33.

Člověk a medicína v totalitárních a demokratických společnostech. Český časopis historický 98, 2000, č. 1, s. 213-215. ISSN 0862-6111. 
Kde se v Praze stonalo před sto lety aneb jak vznikal základ dnešní nemocniční sítě. Zdravotnické noviny 49, 2000, č. 9, s. 12-13. ISSN 0044-1996.

Mezi pitevními stoly a posluchárnami Karolina: pražská univerzitní medicína ve druhé polovině 17. století. Trendy v medicíně 2, 2000, s. 113-114. ISSN 1212-9046.

Pražské středověké špitály. Sanquis 7, 2000, s. 46-50. ISSN 1212-6535.

\section{1}

Dějiny všeobecné nemocnice v Praze 1790-2000: (k 210. výročí založení nemocnice). Ludmila Hlaváčková, Petr Svobodný. 2. rozšířené a upravené vyd. Praha: 2001. 167 s.

Hermann Hubert Knaus (1892-1970). Mediziner: Die Jahre 1938-1945 an der Medizinischen Fakultät der Deutschen Universität in Prag. Alena Míšková, Petr Svobodný. In: Prager Professoren 1938-1948. Zwischen Wissenschaft und Politik. Monika Glettler, Alena Míšková. Essen: Klartext Verlag, 2001, s. 429-441. Veröffentlichungen zur Kultur und Geschichte im östlichen Europa; Bd. 17. ISBN 3-88474-955-2.

A History of Charles University. Vol. I, 1348-1802. Karel Beránek, Ivana Čornejová, Jaroslav Kadlec, Jiří Kejřr, Ludmila Hlaváčková, Marie Pavlíková, Jiří Pešek, Michal Svatoš, Petr Svobodný, František Šmahel. Edited by Ivana Čornejová, Michal Svatoš with collaboration of Petr Svobodný. Prague, The Carolinum Press, 2001. 476 s. [The Medical Faculy s. 171-186; Ludmila Hlaváčková - Petr Svobodný, The Medical faculty, s. 405-438; Ivana Čornejová - Ludmila Hlaváčková - Petr Svobodný, Financial Managment and University Buildings, s. 441-459]. ISBN 80-2460021-8.

A History of Charles University. Vol. II, 1802-1990. Jindřich Bečvár, Břetislav Fajkus, Jan Havránek, Ludmila Hlaváčková, Jan Janko, Jan Jirák, Barbara Köpplová, Miroslav Kunštát, Alena Míšková, Jiří Pešek, Josef Petráň, Zdeněk Pousta, Václav Rusek, Petr Svobodný, Valentin Urfus, Marek Waic, Blanka Zilynská 1. Edited by Jan Havránek, Zdeněk Pousta. Prague: The Karolinum Press, 2001. 403 s. [The Medical Faculty s. 209-213; Jiř́ Pešek - Alena Míšková - Petr Svobodný - Jan Janko; The German University of Prague 1918-1939, s. 245-256; The Medical Faculties, s. 319-331; Václav Rusek - Petr Svobodný, The Pharmaceutical Faculty s. 335]. ISBN 80-246-0022-6.

Dějiny medicíny v Česku let 1993-2000. Dějiny věd a techniky 34, 2001, č. 1, s. 91-100. ISSN 0300-4414.

Informace o společných (mezinárodních) komisích historiků. Český časopis historický 99, 2001, č. 3, s. 658-666. ISSN 0862-6111.

Josef Charvát (1897-1984) Mediziner: Die Kriegsjahre 1939-1945 im Lichte seiner Tagebücher. In: Prager Professoren 1938-1948. Zwischen Wissenschaft und Politik. Monika Glettler, Alena Míšková. Essen: Klartext Verlag, 2001, s. 463-482. Veröffentlichungen zur Kultur und Geschichte im östlichen Europa; Bd. 17. ISBN 3-88474-955-2. 
Lékař a smrt. Ludmila Hlaváčková, Petr Svobodný. In: Fenomén smrti v české kultuře 19. století. Sbornik přispěvki z 20. ročníku sympozia k problematice 19. století, Plzen̆ 9.-11. března 2000. K vydání připravili Helena Lorenzová a Tatána Patrasová. Praha: KLP, 2001, s. 383-398. ISBN 80-85917-79-3.

Die Medizin im Protektorat Böhmen und Mähren. In: Mensch und Medizin in totalitären und demokratischen Gesellschaft. Beiträge zu einer tschechisch-deutschen Tagung der Universitäten Prag und Düsseldorf. Essen: Klartext Verlag, 2001, s. 71-82. ISBN 3-89861-007-1.

České infekční lékarsství od poloviny 19. do poloviny 20. století. Trendy v medicíně 3, 2001, č. 2, s. 56-57.

Informace o Mezinárodním komitétu historických věd (CISH) a o přípravách XX. kongresu historických věd v Sydney. Vilém Prečan, Petr Svobodný. Zpravodaj Historického klubu 12, 2001, č. 1, s. 44-58. ISSN 0862-8513.

Městská nemocnice na Bulovce. Sanquis 2001, č. 18, s. 54-56. ISSN 1212-6535.

Nemocnice alžbětinek a vlašský špitál: Pražské špitály v kontextu zdravotnictví 18. století. Sanquis 2001, č. 10, s. 55-58. ISSN 1212-6535.

Nemocnice na Vinohradech. Sanquis 2001, č. 14/15, s. 80-84. ISSN 1212-6535.

Století lékařek. Dějiny věd a techniky 34, 2001, č. 1, s. 101-102.

Vítězslav Janovský a počátky české vědecké dermatovenerologie. Trendy v medicině 3 , 2001, č. 3, s. 96-97. ISSN 1212-9046.

Vojenská medicína na německé lékařské fakultě v Praze (1939-1945) = Military medicine at the German Faculty in Prague (1939-1945). In: 5. Mezinárodní sympozium k dějinám mediciny, farmacie a veterinární mediciny. Hradec Králové: Vojenská lékařská akademie J. E. Purkyně, 2001, s. 97. ISBN 80-85109-34-4.

\section{2}

„Tak copak Vám scházi“": Komunikace mezi lékařem a pacientem. In: Komunikace a izolace v české kultuře 19. století: sbornik přispěvků z 21. ročniku sympozia k problematice 19. století, Plzeň 8.-10.března 2001. K vydání připravila Kateřina Bláhová. Praha: 2002, s. 44-65. ISBN 80-85917-88-2.

Tři poznámky k otázce, zda bádají ženy jinak: př́pad lékařek. In: Semináře Výzkumného centra pro dějiny vědy z let 2000-2001. Bádaji ženy jinak? Praha: Arenga, 2002, s. 223-225. Práce z dějin vědy; sv. 3. ISBN 80-7285-0150-6. 
Periferie nebo centrum? Místo fakultních nemocnic v rámci zdravotnictví a vysokého školství středoevropské metropole. Documenta Pragensia 20, 2002, s. 425-447. ISSN 0231-7443.

[Kadečková, Helena: Dějiny Islandu]. Dějiny a současnost 24, 2002, č. 1, s. 61-62. ISSN 0418-5129.

[Kohoutová, Margita: Osude, osude...; Horn, Vítězslav: Jak jsem přežil]. Dějiny a současnost 24, 2002, č. 6, s. 61-62. ISSN 0418-5129.

\section{3}

Aktivity československého exilu v oblasti zdravotnictví 1939-1945. In: 6. medzinárodné sympózium $k$ dejinám medicíny, farmácie a veterinárnej medicíny: zborník prác. Darina Heřmanová, Vojtech Ozorovský, Ludmila Pavlíková, Eulália Sedláčková. Bratislava: Univerzita Komenského, 2003. [1 CD: 097pdf.]

Dějiny medicíny na přelomu tisíciletí. Český časopis historický 101, 2003, č. 4, s. 916-927. ISSN 0862-6111.

I festeggiamenti per il giubileo della Congregazione e dell'Ospedale degli italiani nell 1773. In: La Congregazione italiana di Praga. Luoghi e memorie dell'Istituto Italiano di Cultura. Andrea Tretta Cabrales (ed.). Kutná Hora: 2003, s. 89-92, s. 115. ISBN 80-86359-11-5.

Die medizinische Fakultät der Prager deutschen Universität in den Jahren 1938-1945. Rassenhygiene - eine Fallstudie. Vita nostra revue 12, 2003, 12 (Suppl. 1), s. 65-74. ISSN 1212-5083. [Moderne Biologie: Möglichkeiten und Risiken, Hoffnung und Bedrohung. Beiträge zu einer deutsch-tschechischen Tagung der Heinrich Heine Universtität Düsseldorf und Karlsuniversität Prag. Herausgegeben von Michal Andel...]

Tschechische Ärztinnen in der ersten Hälfte des 20. Jahrhunderts. In: Medizinerinnen. Hrsg. Sonia Horn, Ingrid Rias. Wien: 2003, s. 63-70. Wiener Gespräche zur Sozialgeschichte der Medizin. Bd. 3. ISBN 3-901488-38.

L'Ospedale italiano come struttura socio-sanitaria (1602-1789). In: La Congregazione italiana di Praga. Luoghi e memorie dell'Istituto Italiano di Cultura. Andrea Tretta Cabrales (ed.). Kutná Hora: Tichá Byzanc, 2003, s. 26-38, s. 108-109. ISBN 80-86359-11-5.

\section{4}

Continuity and Discontinuity of Health Care in the Czech Lands during two Centuries (1800-2000). Petr Svobodný, Helena Hnilicová, Hana Janečková. Hygiena Internationalis, 4, 2004, Nr. 4, s. 81-107. ISSN 1403-8668. DOI 10.3384/hygiea.1403-8668.0441.

Dějiny lékařství v českých zemich. Petr Svobodný, Ludmila Hlaváčková. Praha: Triton, 2004. 248 s. ISBN 80-7254-424-1. 
The Health of the Population and Health Policy in 19th century Bohemia: The Case of Asiatic Cholera (1830s-1900s). In: European Health and Social Welfare Policies. Laurinda Abreu (Ed.). Santiago de Compostela: Compostela Group of Universities, 2004, s. 200-215. European Issues; vol. 4. ISBN 84-607-3621-X.

Lékaři vzpomínají. AUC-HUCP 43, 2004, fasc. 1-2, s. 280-286. ISSN 0323-0562.

Neue Menschen, neue Disziplinen. Die deutsche Medizinische Fakultät in Prag 1939-1945. In: Wissenschaft in den böhmischen Ländern 1939-1945. Praha: KLP, 2004. s. 143-163. Práce z dějin vědy; sv. 9). ISBN 80-86791-20-3.

Rasová hygiena na lékařské fakultě Německé Karlovy univerzity v Praze (1938-1945). AUC-HUCP 36-38, 1996-1998 [vyd. 2004], s. 61-71. ISSN 0323-0562.

Women Docents and Professors at Medical Faculties in Czechoslovakia 1918-1939. In: Women Scholars and Institutions. Editoři svazku: Soňa Štrbáňová, Ida H. Stamhuis, Kateřina Mojsejová. Praha: Výzkumné centrum pro dějiny vědy, 2004, s. 375-399. Práce z dějin vědy; sv. 13A, ISBN 80-7285-041-5.

Alarich Oldřich. In: Biografický slovnik českých zemí. Sešit 1. Praha: Historický ústav AV ČR, 2004, s. 49. ISBN 80-7277-215-5.

Albert Bohuslav. In: Biografický slovník českých zemí. Sešit 1. Praha: Historický ústav AV ČR, 2004, s. 50. ISBN 80-7277-215-5.

Albrecht Kurt: In: Biografický slovník českých zemí. Sešit 1. Praha: Historický ústav AV ČR, 2004, s. 55. ISBN 80-7277-215-5.

Amerling Karel. In: Biografický slovník českých zemí. Sešit 1. Praha: Historický ústav AV ČR, 2004, s. 78. ISBN 80-7277-215-5.

Amersbach Karel. In: Biografický slovník českých zemí. Sešit 1. Praha: Historický ústav AV ČR, 2004, s. 80. ISBN 80-7277-215-5.

Apetauer Josef. In: Biografický slovník českých zemí. Sešit 1. Praha: Historický ústav AV ČR, 2004, s. 112. ISBN 80-7277-215-5.

[History of Universities]. AUC-HUCP 43, 2003 [vyd. 2004], fasc. 1-2, s. 287-290. ISSN 0323-0562.

[Orel, Vítězslav: Gregor Mendel a počátky genetiky.] Dějiny a současnost 26, 2004, č. 2, s. 58-59. ISSN 0418-5129.

Pražská univerzita v evropském kontextu. AUC-HUCP 36-38, 1996-1998 [vyd. 2004], s. 7-8. ISSN 0323-0562. 
Škorpil Ferdinand. In: Österreichisches Biographisches Lexikon 1815-1950. Lieferung 57. Wien: Verlag der Österreichischen Akademie der Wissenschaften, 2004, s. 330.

[Urbášek, P. - Pulec, J.: Kapitoly z dějin univerzitního školství na Moravě v letech 1945-1990]. Déjiny a současnost 26, 2004, č. 4, s. 61-62. ISSN 0418-5129.

„Zdraví lidu - základ budování“. Propagace socialistického zdravotnictví v rámci komunistické propagandy let 1945-1952. Dějiny a současnost 26, 2004, č. 1, s. 19-23. ISSN 0418-5129.

\section{5}

Dieselbe Leute - neue Karrieren. Die Schicksale der Hochschullehrern der deutschen medizinischen Fakultät in Prag nach 1945. In: Magister Noster. Sborník statí věnovaných in memoriam prof. PhDr. Janu Havránkovi, CSc. k vydání připravili Michal Svatoš, Luboš Velek, Alice Velková; za spolupráce Williama D. Godseye a Ralpha Melvilla. Praha: Nakladatelství Karolinum, 2005, s. 261-274. ISBN 80-246-0753-0.

Health and Health Care in Czechoslovakia 1918-1938: From Infectious to Civilisation Diseases. Hana Mášová, Petr Svobodný. In: Facing Illness in Troubled Times. Health in Europe in the Interwar Years 1918-1939. Iris Borowy, Wolf D. Gruner (eds.). Frankfurt am Main: Peter Lang GmbH, 2005, s. 165-205. ISBN 3-631-51948-6.

Kapitoly z dějin lékařství. Milada Ř́hová a kol. Praha: Karolinum, 2005. 139 s. [Mezi dvěma světovými válkami, s. 102-114 (Hana Mášová, Petr Svobodný); Od roku 1945 do nedávné minulosti, s. 125-135 (Hana Mášová, Petr Svobodný). Za druhé světové války, s. 115-124]. ISBN 80-246-1021-3.

Die Losung vom „einheitlichen sozialistischen Gesundheitswesen“ in der Fachpresse im Rahmen der kommunistischen Propaganda (1945-1952). In: Propaganda (Selbst-Zensur, Sensation. Grenzen von Presse- und Wissenschaftsfreiheit in Deutschland und Tschechien seit 1871). Michal Anděl, Detlef Brandes, Alfons Labisch, Jiří Pešek, Thomas Růžička (Hrsg.) Essen: Klartext, 2005, s. 261-271. ISBN 3-89861-456-5.

Propagace socialistického zdravotnictví v rámci komunistické propagandy (1945-1952). In: České zdravotnictví: vize a skutečnost: složité peripetie od plánů k realizaci. Editoři: Hana Mášová, Eva Kř́žžová, Petr Svobodný. Praha: Nakladatelství Karolinum, 2005, s. 111-132. ISBN 80-246-0944-4.

German „Social Hygiene“ in the Service for Czechoslovak „Social Medicine“ and Public Health Administration. In: Cultural History of Health and Beyond. Programme and Book of Abstracts. Paris: 2005, s. 124.

Bárta Josef. In: Biografický slovník českých zemí. Sešit 2. Praha: Historický ústav AV ČR, 2005, s. 223. ISBN 80-7277-252-X. 
Barták František. In: Biografický slovník českých zemí. Sešit 2. Praha: Historický ústav AV ČR, 2005, s. 223. ISBN 80-7277-252-X.

Basař Svatopluk. In: Biografický slovník českých zemí. Sešit 3. Praha: Historický ústav AV ČR, 2005, s. 264. ISBN 80-7277-287-2.

Baštecký Jan. In: Biografický slovník českých zemí. Sešit 3. Praha: Historický ústav AV ČR, 2005, s. 271-272. ISBN 80-7277-287-2.

Baštýř Moses (Moric). In: Biografický slovník českých zemí. Sešit 3. Praha: Historický ústav AV ČR, 2005, s. 270. ISBN 80-7277-287-2.

Bayerová Anna. In: Biografický slovník českých zemí. Sešit 3. Praha: Historický ústav AV ČR, 2005, s. 270. ISBN 80-7277-287-2.

Bedrna Jan. In: Biografický slovník českých zemí. Sešit 3. Praha: Historický ústav AV ČR, 2005, s. 329. ISBN 80-7277-287-2.

Bena Eduard. In: Biografický slovník českých zemí. Sešit 3. Praha: Historický ústav AV ČR, 2005, s. 362. ISBN 80-7277-287-2.

[Hana Mášová: Nemocniční otázka v meziválečném Československu]. Český časopis historický 103, 2005, č. 3, s. 716-717. ISSN 0862-6111.

Jan Horbaczewski. Časopis lékařů českých 144, 2005, č. 9, s. 656. ISSN 0008-7335.

Jan Marek Marci z Kronlandu. Časopis lékařu českých 144, 2005, č. 3, s. 216. ISSN 0008-7335.

Karel Maydl. Časopis lékařu českých 144, 2005, č. 10, s. 776. ISSN 0008-7335.

Lékařství ve 2. světové válce. Proměny lékařského stavu. Petr Svobodný, Ludmila Hlaváčková. Praktický lékař 85, 2005, č. 5, s. 273-276. ISSN 0032-6739.

Lothar Tirala: závratná kariéra brněnského gynekologa v třetí ř́ši. In: 7. mezinárodní sympózium k dějinám medicíny, farmacie a veterinární medicíny: Abstrakta. Olomouc: 2005, s. 60. ISBN 80-244-1043-5.

Mezinárodní konference o kulturních dějinách medicíny, zdravotnictví a zdraví. Dějiny věd a techniky 38, 2005, č. 4, s. 286-288. ISSN 0300-4414.

Podzimní setkání sociologů a historiků medicíny zdravotnictví. Hana Mášová, Eva Křížová, Petr Svobodný. In: České zdravotnictví: vize a skutečnost. Složité peripetie od plánů k realizaci. Praha: Karolinum, 2005, s. 9-11. ISBN 80-246-0944-4. 
Rozvoj pražských fakultních nemocnic v historické perspektivě. Forum 2005, č. 3, s. 38-40. ISSN 1211-1724.

Rudolf Jedlička. Časopis lékařu českých 144, 2005, č. 12, s. 864. ISSN 0008-7335.

Sobek Soběslav. In: Österreichisches Biographisches Lexikon 1815-1950. Lieferung 58. Wien: Verlag der Österreichischen Akademie der Wissenschaften, 2005, s. 385-386.

Soyka Isidor. In: Österreichisches Biographisches Lexikon 1815-1950. Lieferung 58. Wien: Verlag der Österreichischen Akademie der Wissenschaften, 2005, s. 439-440.

Smička František. In: Österreichisches Biographisches Lexikon 1815-1950. Lieferung 58. Wien: Verlag der Österreichischen Akademie der Wissenschaften, 2005, s. 370.

\section{6}

I lékaři a pacienti vzpomínají. In: Paměti a vzpomínky jako historický pramen. Milada Sekyrková (ed.). Praha: Národní technické muzeum, 2006, s. 319-338. ISBN 80-7037-1528. Práce z dějin techniky a prírodních věd; sv. 10.

Proč jsem se rozhodl/a pro lékařské povolání? Soukromé rozhodnutí ve prospěch veřejnosti ve světle pamětí. In: Historia - Medicina - Cultura. Sborník k dějinám medicíny. Karel Černý, Petr Svobodný (eds.). Praha: Karolinum, 2006, s. 265-289. ISBN 80-246-1099-X.

Benešová Dagmar. In: Biografický slovník českých zemí. Sešit 4. Praha: Historický ústav AV ČR, 2006, s. 401. ISBN 80-7277-299-6.

Bergauer Vladimír. Petr Svobodný, Josef Tomeš. In: Biografický slovník českých zemí. Sešit 4. Praha: Historický ústav AV ČR, 2006, s. 422. ISBN 80-7277-299-6.

Beutel Alois. In: Biografický slovnik českých zemí. Sešit 4. Praha: Historický ústav AV ČR, 2006, s. 463. ISBN 80-7277-299-6.

Bezecný Rudolf. In: Biografický slovnik českých zemí. Sešit 4. Praha: Historický ústav AV ČR, 2006, s. 474. ISBN 80-7277-299-6.

Bláha František. In: Biografický slovnik českých zemí. Sešit 5. Praha: Historický ústav AV ČR, 2006, s. 528-529. ISBN 80-7277-309-7.

Bláha Karel. In: Biografický slovník českých zemí. Sešit 5. Praha: Historický ústav AV ČR, 2006, s. 532. ISBN 80-7277-309-7.

Bláha Roman. In: Biografický slovník českých zemí. Sešit 5. Praha: Historický ústav AV ČR, 2006, s. 532-533. ISBN 80-7277-309-7. 
Blažek František. In: Biografický slovník českých zemí. Sešit 5. Praha: Historický ústav AV ČR, 2006, s. 550. ISBN 80-7277-309-7.

Blecha Jiří. In: Biografický slovnik českých zemí. Sešit 5. Praha: Historický ústav AV ČR, 2006, s. 562. ISBN 80-7277-309-7.

Edward Babák. Časopis lékařu českých 145, 2006, č. 1, s. 84. ISSN 0008-7335.

František Burian. Časopis lékařu českých 145, 2006, č. 2, s. 168. ISSN 0008-73355.

František Patočka. Časopis lékařu českých 145, 2006, č. 11, s. 892. ISSN 0008-7335.

[Friedhelm Golücke, Verfasserlexikon zur Studenten- und Universitätsgeschichte. Ein bio-bibliographisches Verzeichnis]. AUC-HUCP 45, 2005 [vyd. 2006], fasc. 1-2, s. 173-174. ISSN 0323-0562.

[H. Lemberg (Hg.), Universitäten in nationaler Konkurrenz.] AUC-HUCP 44, 2004 [vyd. 2006], fasc. 1-2, s. 266-268. ISSN 0323-0562.

Hermann Hubert Knaus. Časopis lékařu českých 145, 2006, č. 7, s. 592. ISSN 0008-7335.

Heřman Šikl. Časopis lékařů českých 145, 2006, č. 4, s. 340. ISSN 0008-7335.

Jezuité a Klementinum. Dějiny věd a techniky 39, 2006, č. 1, s. 138-139. ISSN 0300-4414.

Johannes Jessenius. Forum 2006, č. 2, s. 19-20. ISSN 1211-1724.

Josef Charvát. Časopis lékařu českých 145, 2006, č. 10, s. 820. ISSN 0008-7335.

Kamil Henner. Časopis lékařu českých 145, 2006, č. 9, s. 680. ISSN 0008-7335.

Publikace k dějinám československého vysokého školství ve 20. století. AUC-HUCP 44, 2004 [vyd. 2006], fasc. 1-2, s. 262-265. ISSN 0323-0562.

Rektoři pražských univerzit ve vírech politiky 20. století. Marek Ďurčanský, Zdeněk Pousta, Petr Svobodný. Forum 2006, č. 1, 47-51. ISSN 1211-1724.

Vilém Laufberger. Časopis lékařu českých 145, 2006, č. 6, s. 508. ISSN 0008-7335.

V. J. Krombholz. Forum 2006, č. 1, s. 30. ISSN 1211-1724.

\section{7}

[IX. sjezd českých historiků.] Série C: Historie v kontextu ostatních vědních disciplín. Marie Macková, Petr Svobodný. Český časopis historický 105, 2007, č. 1, s. 248-252. ISSN 0862-6111. 
Spina Arnold. F. Spurný, P. Svobodný. In: Österreichisches Biographisches Lexikon 1815-1950. Lieferung 59. Wien: Verlag der Österreichischen Akademie der Wissenschaften, 2007, s. 28-29. ISBN 978-3-7001-3864-8.

Starkenstein Emil. In: Österreichisches Biographisches Lexikon 1815-1950. Lieferung 59. Wien: Verlag der Österreichischen Akademie der Wissenschaften, 2007, s. 109-110. ISBN 978-3-7001-3864-8.

Institucionální péče ve středověku a raném novověku. Petr Svobodný, Ludmila Hlaváčková. In: Zborník príspevkov z 8. medzinárodného sympózia o dejinách mediciny, farmácie a veterinárnej medicíny 27.-29. Júna 2007. Martin: Jesseniova lekárska fakulta UK, 2007. ISBN 978-80-88866-44-2 [ CD-ROM].

Social and Health Care of Children in Central Europe: The Italian Hospital in Prague in the 17th-18th Century. Hygiena Internationalis 6, 2007, Nr. 1, s. 79-92. ISSN 1403-8668.

Česká lékařská fakulta a městské zdravotní a sociální ústavy za protektorátu (1939-1945). In: V komnatách paláců, v ulicích měst: Sborník př́spěvků věnovaných V. Ledvinkovi k 60. narozeninám. K vydání připravili Kateřina Jíšová, Olga Fejtová a kol. Praha: Scriptorium, 2007, s. 181-204. ISBN 978-80-86197-79-1.

Němečtí sociální hygienici ve službách sociálního lékařství a veřejného zdravotnictví v meziválečném Československu (1918-1939). AUC-HUCP 47, fasc. 1-2, 2007, s. 247-264. ISSN 0323-0562.

Borovanský Ladislav. In: Biografický slovnik českých zemí. Sešit 6. Praha: Historický ústav AV ČR, 2007, s. 64-65. ISBN 978-80-7277-239-1.

Bouček Bohuslav. In: Biografický slovnik českých zemí. Sešit 6. Praha: Historický ústav AV ČR, 2007, s. 91. ISBN 978-80-7277-239-1.

Brandejs Matěj. In: Biografický slovník českých zemí. Sešit 7. Praha: Historický ústav AV ČR, 2007, s. 130. ISBN 978-80-7277-248-3.

Breinl Friedrich. In: Biografický slovník českých zemí. Sešit 7. Praha: Historický ústav AV ČR, 2007, s. 162-163. ISBN 978-80-7277-248-3.

Brosch Friedrich. In: Biografický slovník českých zemí. Sešit 7. Praha: Historický ústav AV ČR, 2007, s. 198. ISBN 978-80-7277-248-3.

Bruckner Záboj. In: Biografický slovnik českých zemí. Sešit 7. Praha: Historický ústav AV ČR, 2007, s. 217. ISBN 978-80-7277-248-3.

Brumlík Josef. In: Biografický slovník českých zemí. Sešit 7. Praha: Historický ústav AV ČR, 2007, s. 223-224. ISBN 978-80-7277-248-3. 
Bukovský Jaroslav. In: Biografický slovník českých zemí. Sešit 8. Praha: Historický ústav AV ČR, 2007, s. 305. ISBN 978-80-7277-257-5.

Bumba Josef. In: Biografický slovník českých zemí. Sešit 8. Praha: Historický ústav AV ČR, 2007, s. 316. ISBN 978-80-7277-257-5.

Burian František. In: Biografický slovník českých zemí. Sešit 8. Praha: Historický ústav AV ČR, 2007, s. 341-342. ISBN 978-80-7277-257-5.

[M. Lenderová - K. Rýdl, Radostné dětství.] Dějiny a současnost 29, 2007, č. 3, s. 45. ISSN 0418-5129.

\section{8}

Czech Experience with Specialised Archives: Shared Concern and Responsibility for Dissertations, Comma 2007, ICA'Section on University and Research Institution Archives: Selected Dialogue from the Formative Years. [CD-ROM - vyšlo 2008].

Dějiny medicíny jako kongresové téma. In: IX. Sjezd českých historiků. Pardubice 6.-8. zárí 2006. Sv. II. Historie v kontextu ostatních vědních disciplín. Brno - Pardubice Praha - Ústí nad Labem: Sdružení historiků České republiky, 2008, s. 365-379. ISBN 978-80-904069-1-9.

Hermann Hubert Knaus - profesor lékařské fakulty Německé (Karlovy) univerzity v Praze v letech 1938-1945. AUC-HUCP 48, 2008, fasc. 1, s. 111-122. ISSN 0323-0562.

Social and Health Care of Children in Central Europe: The Italian Hospital in Prague in the 17th-18th Centuries. In: The Price of Life. Welfäre Systems, Social Nets and Economic Growth. Laurinda Abreu, Patrice Bourdelais, eds. Lisboa: Ediçoes Colibri-CIDEHUS/UE, 2008, s. 317-332. ISBN 978-972-772-779-7.

Die Spitäler in Böhmen und Mähren im Mittelalter und der frühen Neuzeit. In: Europäisches Spitalwesen: Institutional Care in Medieval and Early Modern Europe. Hrsg. von Martin Scheutz et al. Wien; München: R. Oldenbourg Verlag, 2008, s. 351-380. Mitteilungen des Instituts für Österreichische Geschichtsforschung. Ergänzugsband 51, 2008. ISSN 1817-8774.

Cassing de Bugella Jan Antonín. In: Biografický slovník českých zemí. Sešit 9. Praha: Historický ústav AV ČR, 2008, s. 394-395. ISBN 978-80-7277-366-4.

Císler Josef. Petr Svobodný, Marcella Husová. In: Biografický slovník českých zemí. Sešit 9. Praha: Historický ústav AV ČR, 2008, s. 431-432. ISBN 978-80-7277-366-4.

Čapek Dominik. In: Biografický slovnik českých zemí. Sešit 10. Praha: Historický ústav AV ČR, 2008, s. 519. ISBN 978-80-7277-367-1. 
Čížková-Písařovicová Jiřina. In: Biografický slovník českých zemí. Sešit 11. Praha: Historický ústav AV ČR, 2009, s. 87. ISBN 978-80-7277-368-8.

\section{9}

František Hájek: A Czech Professor of Forensic Medicine in Katyn: With Suplementary Information on Professors F. Šubík (Slovakia) and M. A. Markov (Bulgaria). In: Katyn et la Suisse: Experts et expertises médicales dans les crises humanitaires, 1920-2007 = Katyn and Switzerland: Forensic Investigators and Ivestigations in Humanitarian Crises, 1920-2007. Delphine Debons, Antoine Fleury, Jean-Francois Pitteloud (eds). Geneve: Georg Editeur, 2009, s. 155-165. ISBN 978-2-8257-0959-7.

František Hájek - český profesor soudního lékařství v Katyni. AUC-HUCP 48, 2008 [vyd. 2009], fasc. 2, s. 33-51. ISSN 0323-0562.

Prague Faculties of Medicine and their Clinics in 1939-1945. In: Wissenschaft macht Politik: Hochschule in den politischen Systembrüchen 1933 und 1945. Sabine Schleiermacher, Udo Schagen (Hg.). Stuttgart: Franz Steiner Verlag, 2009, s. 219-228. Wissenschaft, Politik und Gesellschaft ; Bd. 3. ISBN 978-3-515-09315-6.

[Medicína v kontextu západního myšlení. Ed. Lydie Fialová, Pavel Kouba, Martin Špaček]. AUC-HUCP 48, 2008 [vyd. 2009], fasc. 2, s. 103-105. ISSN 0323-0562.

Středověké a raně novověké špitály v českých zemích. Medical tribune 5, 2009, č. 11, C6. ISSN 1214-8911.

Čížková-Písařovicová Jiřina. In: Biografický slovník českých zemí. Sešit 11. Praha: Historický ústav AV ČR, 2009, s. 87. ISBN 978-80-7277-368-8.

David Václav. In: Biografický slovník českých zemí. Sešit 12. Praha: Historický ústav AV ČR, 2009, s. 147-148. ISBN 978-80-7277-415-9.

Deyl Jan. In: Biografický slovnik českých zemí. Sešit 12. Praha: Historický ústav AV ČR, 2009, s. 190-191. ISBN 978-80-7277-415-9.

Diviš Jiří. In: Biografický slovnik českých zemí. Sešit 12. Praha: Historický ústav AV ČR, 2009, s. 235. ISBN 978-80-7277-415-9.

\section{0}

Lékařské fakulty - noční můra rektorů (a historiků univerzit). Východočeské listy historické 27, 2010, s. 40-51. ISSN 1211-8184.

Lothar Gottlieb Tirala: Závratná kariéra brněnského gynekologa ve „třetí ř́íši“. Dějiny věd a techniky 43, 2010, č. 2, s. 113-129. ISSN 0300-4414. 
Domanský Karel. In: Biografický slovník českých zemí. Sešit 13. Praha: Historický ústav AV ČR, 2010, s. 302. ISBN 978-80-7277-416-6.

Dosužkov Fjodor. In: Biografický slovník českých zemí. Sešit 13. Praha: Historický ústav AV ČR, 2010, s. 337-338. ISBN 978-80-7277-416-6.

\section{1}

Dějiny všeobecné fakultní nemocnice v Praze 1790-2010. Ludmila Hlaváčková, Petr Svobodný, Jan Bříza. 3. rožs. vyd. Praha: Maxdorf, 2011. 231 s., př́l. ISBN 978-80-7345-243-8.

Die Hämatologie an der Prager Medizinischen Fakultäten vom Ausgang des 19. bis zur Mitte des 20. Jahrhunderts. In: Blut: Perspektiven in Medizin, Geschichte und Gesellschaft. Jiří Pešek, Falk Wiesejmann (Hrsg.) Essen: Klartext, 2011, s. 219-230. Veröffentlichungen zur Kultur und Geschichte im östlichen Europa; Bd. 38 ISBN 978-3-8375-0503-0.

Chemie na lékařských fakultách v Praze, Vídni a Lipsku (1872-1945). AUC-HUCP 50, 2010 [vyd. 2011], fasc. 2, s. 15-86. ISSN 0323-0562.

1. lékařská fakulta UK ve zkratce. Ludmila Hlaváčková, Petr Svobodný. In: 1. lékařská fakulta UK v běhu času. Uspořádali Vlasta Helekalová, Jaroslav Hořejší. Praha: Galén, 2011, s. 9-84. ISBN 978-80-7262-570-3.

Př́spěvky k dějinám Masarykovy univerzity. Český časopis historický 109, 2011, č. 4, s. 786-793. ISSN 0862-6111.

Wanderungen und Wandlungen: Die medizinische Fakultät der Deutschen Universität und ihre Beziehungen zu deutschen und österreichischen Universitätren in den Jahren 1882 1945. In: Zehn Jahre Universitätspartnerschaft Univerzita Karlova v Praze - Universität zu Köln. Kolloquium zur Universitäts-und Fachgeschichte. Herausgegeben von Walter Pape. Köln: Universitäts- und Stadtbibliothek Köln, 2011, s. 15-30. Elektronische Schriftenreihe der Universitäts- und Stadtbibliothek Köln. ISBN 978-3-931596-57-6.

Annus jubileus. Michal Svatoš, Petr Svobodný, Blanka Zilynská. AUC-HUCP 50, 2010 [vyd. 2011], fasc. 1, s. 11-12. ISSN 0323-0562.

[Bohemia docta.]. Dějiny věd a techniky 44, 2011, č. 2, s. 123-125.

Body and Mind in the History of Medicine and Health. Dějiny věd a techniky 44, 2011, č. 4, s. 278-281.

90 let vysokoškolského vzdělávání a vědy na Slovensku. AUC-HUCP 50, 2010 [vyd. 2011], fasc. 1, s. 273-275. ISSN 0323-0562.

Dvě berlínská výročí. $A U C-H U C P$ 50, 2010 [vyd. 2011], fasc. 2, s. 142-146. ISSN 0323-0562. 
Evropské časopisy pro dějiny univerzit. AUC-HUCP 50, 2010 [vyd. 2011], fasc. 2, s. 140-142. ISSN 0323-0562.

Proč připomínáme Bohuslava Rýmana. Práce z dějin Akademie věd 3, 2011, č. 2, s. 159-160. ISSN 1803-9448.

Příspěvky k dějinám Masarykovy univerzity. Český časopis historický 109, 2011, č. 4, s. 786-793.

\section{2}

17. listopad 1939 a 1989: čeští univerzitní studenti v období totalitních režimů v současné historiografii a kultuře vzpomínání. $A U C-H U C P$ 52, 2012, Suppl. 1, s. 133-142. ISSN 0323-0562.

Dokument ke konci pražské německé lékařské fakulty v květnu 1945. Michal Šimůnek, Petr Svobodný. AUC-HUCP 51, 2011 [vyd. 2012], fasc. 1, s. 85-89. ISSN 0323-0562.

History of European Universities: Challenges and Transformations. Lisabon, duben 2011. AUC-HUCP 51, 2011 [vyd. 2012], fasc. 1, s. 98-101. ISSN 0323-0562.

Spolek českých lékařů v běhu dějin. Časopis lékařů českých 151, 2012, č. 8, s. 12-14, příl. ISSN 0008-7335.

[Jiří Pešek - Tomáš Nigrin (edd.), Ostrovy občanské autonomie? Tradiční samosprávné instituce v převratových letech 1944/45 a 1989/90]. AUC-HUCP 51, 2011 [vyd. 2012], fasc. 1, s. 107-108. ISSN 0323-0562.

Universities in Central Europe: Changing Perspetives in the Troubled 20th Century. In: Universities in Central Europe - Crossroads of Scholars from All over the World: 29 September - 1 October, 2011, Charles University in Prague, Czech Republic: conference proceedings. Milada Sekyrková, Petr Cajthaml (eds.). Prague: Institute of the History of Charldes University and Archive of Charles University, 2012, s. 17-24. [CD-ROM]. ISBN 978-80-87489-05-5.

\section{3}

Eiselt Rudolf Richard. In: Biografický slovník českých zemí. Seš. 15. Praha: Academia, 2013, s. 554. ISBN 978-80-7277-504-0.

Evropské časopisy k (soudobým) dějinám medicíny. In: Napřič kontinentem soudobých dějin: Evropská historiografie po konci studené války. Jiří Pešek, Jan Bečka, David Emler (ed.). Praha: Argo, 2013, s. 196-214. Historické myšlení; sv. 64. ISBN 978-80-257-1053-1.

Feierabend Bohuslav. In: Biografický slovník českých zemí. Seš. 16. Praha: Academia, 2013, s. 89-90. ISBN 978-80-200-2292-9. 
Epstein Berthold. In: Biografický slovník českých zemí. Seš. 16. Praha: Academia, 2013, s. 3. ISBN 978-80-200-2292-9.

The Medical Faculty of the German Charles University in Prague 1939-1945 with Special Consideration of its Relations to the University of Münster. In: Medizinische Fakultäten in der deutschen Hochschullandschaft 1925-1950. Ursula Ferdinand, Hans-Peter Krönner, Ioanna Mamali (eds.). Heidelberg: Synchron, 2013, s. 329-339. Studien zur Wissenschaftsund Universitätsgeschichte; Bd. 16. ISBN 978-3-939381-67-9.

[Eva Chodějovská (red.), Historický atlas měst ČR, sv. 24 - Praha-Smíchov]. Dějiny věd a techniky 46, 2013, č. 3, s. 211-213. ISSN 0300-4414.

[Toomas Hiio - Helmut Piirimäe (eds.), Universitas Tartuensis 1632-2007]. AUC-HUCP 52, 2012 [vyd. 2013], fasc. 2, s. 147-151. ISSN 0323-0562.

\section{4}

Fingerland Antonín: In: Biografický slovník českých zemí. Seš. 17. Praha: Academia, 2014, s. 203. ISBN 978-80-200-2424-4.

Fischer Ludvík: In: Biografický slovník českých zemí. Seš. 17. Praha: Academia, 2014, s. 228. ISBN 978-80-200-2424-4.

History of the General University Hospital in Prague. Ludmila Hlaváčková, Petr Svobodný, Jan Bříza. Prague: Nová Forma s. r. o., 2014. 129 s. ISBN 978-80-7453-440-9.

Pozůstalosti lékar̆ů v AUK v Praze. In: Zdraví a nemoc v dějinách člověka a zvírat. Ed. Radek Slabotínský, Pavla Stöhrová. Brno: Technické muzeum v Brně, 2014, s. 73-81. Acta Musei technici Brunensis; sv. 5. ISBN 978-80-87896-09-9.

Reakce mezinárodní veřejnosti na pronásledování české a polské inteligence. In: Trpké vzpomínky na 17. listopad 1939. Zdeněk Pousta (ed.). Praha: Karolinum, 2014, s. 195-201. ISBN 978-80-246-2824-0.

Rok 1945 v životě profesora Josefa Charváta. In: Deník Josefa Charváta z roku 1945. Ed. Marie Bahenská, Hana Barvíková. Praha: Nakladatelství Lidové noviny, 2014, s. 11-18. ISBN 978-80-7422-284-9.

[Alica Kapellerová - Lázsló Kovács, 150 rokov bratislavskej detskej nemocnice]. Dějiny věd a techniky 47, 2014, č. 4, s. 262-264. ISSN 0300-4414.

[Michal V. Šimůnek - Antonín Kostlán (eds.), Disappeared Science. Jewish Scholars from Bohemia and Moravia - Victims of Nazism, 1939-1945]. Dějiny věd a techniky 47, 2014, č. 2, s. 129-131. ISSN 0300-4414. 
Z historie Ortopedické kliniky 2. LF UK Praha a FN Motol v Praze. Vladislav Mrzena, Petr Svobodný. Medicína a umění 2014, č. 5 (33), s. 9-14. ISSN 1803-3679.

\section{5}

Rudolf Kimla: profesor LF UK v Praze a člen PAU v Krakově. K dějinám česko-polských vědeckých vztahů. Historia Slavorum Occidentis 5, 2015, No. 1 (8), s. 192-211. ISSN 2084-1213.

Tři generace rodiny Aloise Klara - tři fáze péče o nevidomé v Čechách. In: Útisk, charita, vyloučení - sociálni 19. století: sbornik přispěvků z 34. ročníku mezioborového sympozia k problematice 19. století: Plzen̆, 27. 2. - 1. 3. 2014. Uspoř. Zdeněk Hojda, Marta Ottlová a Roman Prahl. Praha: Academia, 2015, s. 170-189. ISBN 978-80-200-2460-2.

Franchimont Mikuláš. In: Biografický slovník českých zemí. Seš. 18. Praha: Academia, 2015, s. 338. ISBN 978-80-200-2517-3.

Frankenberger Otakar. In: Biografický slovník českých zemí. Seš. 18. Praha: Academia, 2015, s. 345-346. ISBN 978-80-200-2517-3.

Formánek Emanuel. In: Biografický slovník českých zemí. Seš. 18. Praha: Academia, 2015, s. 203-203. ISBN 978-80-200-2517-3.

Universities in Central Europe: Changing Perspectives in the Troubled Twentieth Century. In: Sciences in the Universities of Europe, 19th and 20th Century. Ana Simoes, Maria P. Diogo, Kostas Gavroglu (eds.). Dordrecht: Springer, 2015, Boston studies in philosophy and history of science, 309, s. 107-123. ISBN 978-94-017-9635-4.

Z historie ortopedické kliniky 2. LFUK Praha a FN Motol. Vladislav Mrzena, Petr Svobodný. Pohybové ústrojí. Pokroky ve výzkumu, diagnostice a terapii 22, 2015, č. 1-2, s. 110-120. ISSN 14575.

[Anatomie od Vesalia po současnost 1514-2014. Miloš Grim, Ondřej Naňka, Karel Černý (eds.)]. Časopis lékař̀i českých 154, 2015, č. 1, s. 52. ISSN 0008-7335.

[Martin Vonka: Tovární komíny: funkce - konstrukce - architektura]. Dějiny věd a techniky 48,2015 , č. 1 , s. $58-59$.

[Od špitála k nemocnici. Zdravotníctvo, sociálna starostlivost' a osveta v dejinách Slovenska. Ed. Ivana Fialová, Daniel Tvrdoňová. Bratislava: Slovenský národný archív, 2013.] Dějiny věd a techniky 48, 2015, č. 1, s. 50-51. ISSN 0300-4414.

[Ulrich von Hehl - Günther Heydemann - Klaus Fitschen - Klaus König, Geschichte der Universität Leipzig 1409-2009, III, Das zwanzigste Jahrhundert 1909-2009]. AUC-HUCP 53, 2013 (vyd. 2015), fasc. 2, s. 194-197. ISSN 0323-0562. 


\section{6}

Dějiny medicíny (převážně) v Německu na počátku 21. století: Bilance a perspektivy. AUC-HUCP 56, 2016, fasc. 1, s. 217-223. ISSN 0323-0562.

Fürst Adolf. In: Biografický slovnik českých zemí. Seš. 19. Praha: Academia, 2016, s. 507-508. ISBN 978-80-200-2625-5.

Gála Cyril. In: Biografický slovnik českých zemí. Seš. 19. Praha: Academia, 2016, s. 543-543. ISBN 978-80-200-2625-5.

Gamper Eduard. In: Biografický slovník českých zemí. Seš. 19. Praha: Academia, 2016, s. 559. ISBN 978-80-200-2625-5.

Gawalowski Karel. In: Biografický slovník českých zemí. Seš. 19. Praha: Academia, 2016, s. 580. ISBN 978-80-200-2625-5.

[Pieter Dhondt (ed.), University Jubilees and University History Writing. A Challenging Relationship (Scientific and Learned Cultures and Their Institutions, Vol. 13)]. AUC-HUCP 55, 2015 [vyd. 2016], fasc. 2, s. 165-168. ISSN 0323-0562.

\section{7}

Inaugural Addresses of Prague University Rectors between Science and Providing Service to Society, Nation and State in the First Half of the 20th Century. In: The Elite University - Roles and Models. Edited by Ditlev Tamm. Copenhagen: Det Kongelige Dabske Videnskabernes Selskab, 2017, s. 122-145. Scientia Danica. Series H 8, vol. 15. ISBN 978-87-7304-409-4, ISSN 1904-5492.

Lékařské fakulty, nebo lékařské akademie? Vysokoškolská výuka medicíny a lékařská věda v sovětském bloku ve 40 . až 60 . letech 20. století. Dějiny věd a techniky 50, 2017, č. 1, s. 9-27.

Gotsch Karl. In: Biografický slovnik českých zemí. Seš. 20. Praha: Academia, 2017, s. 691-692. ISBN 978-80-7286-307-5.

Greif Karel. In: Biografický slovník českých zemí. Seš. 20. Praha: Academia, 2017, s. 740. ISBN 978-80-7286-307-5.

Gruschka Theodor. In: Biografický slovník českých zemí. Seš. 20. Praha: Academia, 2017, s. 796-797. ISBN 978-80-7286-307-5.

Gutwirth Alois. In: Biografický slovník českých zemí. Seš. 20. Praha: Academia, 2017, s. 833. ISBN 978-80-7286-307-5. 


\section{Editorská a redakční činnost}

A Guide to Historical Institutes, History Departments, Archives and Museums in the Czechoslovak Republic: The Czech National Committee of Historians for the Participants of the 18th International Congress of Historical Science, Montréal 1995. Compl. by Petr Svobodný, transl. from the Czech Derek Paton. Prague : Institute for Contemporary History, 1995. $104 \mathrm{~s}$.

Acta Universitatis Carolinae. Historia Universitatis Carolinae Pragensis. Př́spěvky k dějinám Univerzity Karlovy. Uspořádal Petr Svobodný, 35, 1995 [vyd. 1996], fasc. 1-2. 217 s.

Profesionalizace akademických povolánív českých zemích v 19. a první polovinè 20. století. Uspořádali Jan Havránek, Petr Svobodný. Praha: Univerzita Karlova, 1996. 146 s. ISBN 80-7184-081-5.

3. česko-slovenské sympozium $k$ dějinám medicíny, farmacie a veterinární mediciny s mezinárodni účastí: 25.-27. června 1996 Benešov u Prahy. Abstrakta. [K vydání připravili L. Hlaváčková, H. Mášová, E. Strouhal, P. Svobodný, E. Těšínská]. Praha: Ústav dějin lékařství, 1996. $103 \mathrm{~s}$.

Sbornik k 100. výroči narození profesora MUDr. Jana Bělehrádka (1896-1980). Uspořádal Petr Svobodný. Praha: Nakladatelství Karolinum, 1997. 47 s. ISBN 80-7184-699-6.

Joannes Marcus Marci: a seventeenth-century Bohemian Polymath. Edited by Petr Svobodný. Prague: Charles University Press, 1998. 236 s. ISBN 80-7184-475-6.

Véda v Československu v letech 1945-1953: sbornik z konference (Praha 18.-19. listopadu 1998. Editoři svazku Blanka Zilynská, Petr Svobodný. Praha: Ústav dějin - Archiv UK, 1999. 563 s. ISBN 80-7184-959-6.

Acta Universitatis Carolinae. Historia Universitatis Carolinae Pragensis. Př́spěvky k dějinám Univerzity Karlovy. Uspořádali Petr Svobodný a Blanka Zilynská, 39, 1999 [vyd. 2000], fasc. 1-2. $188 \mathrm{~s}$.

A Guide to Historical Institutes, History Departments, Archives and Museums in the Czechoslovak Republic: The Czech National Committee of Historians for the Participants in the 19th International Congress of Historical Sciences, Oslo 2000. Compl. by Petr Svobodný, transl. from the Czech by Derek Paton and Todd Hammomd. Prague: Institute of Contemporary History, 2000. 112 s.

Ad maiorem academiae gloriam: sborník prací PhDr. Karla Beránka vydaný u př́ležitosti jeho životního jubilea. Uspořádal Petr Svobodný, na př́ípravě svazku spolupracovala Blanka Šachová. Praha: Karolinum, 2000. 174 s. Příspěvky k dějinám vzdělanosti v českých zemích; sv. 3. ISBN 80-246-0138-9.

A History of Charles University. Vol. I, 1348-1802. Karel Beránek, Ivana Čornejová, Jaroslav Kadlec, Jiří Kejř, Ludmila Hlaváčková, Marie Pavlíková, Jiří Pešek, Michal Svatoš, 
Petr Svobodný, František Šmahel. Edited by Ivana Čornejová, Michal Svatoš with collaboration of Petr Svobodný. Prague, The Carolinum Press, 2001. 476 s. ISBN 80-246-0021-8.

A History of Charles University. Vol. II, 1802-1990. Jindřich Bečváŕ, Břetislav Fajkus, Jan Havránek, Ludmila Hlaváčková, Jan Janko, Jan Jirák, Barbara Köpplová, Miroslav Kunštát, Alena Mišková, Jiř́i Pešek, Josef Petráň, Zdeněk Pousta, Václav Rusek, Petr Svobodný, Valentin Urfus, Marek Waic, Blanka Zilynská 1. Edited by Jan Havránek, Zdeněk Pousta. Prague: The Karolinum Press, 2001. 403 s. ISBN 80-246-0022-6.

Česká věda a Pražské jaro (1963-1970): sbornik z konference (Praha 22.-23. listopadu 2000). Editoři svazku: Blanka Zilynská a Petr Svobodný. Praha: Karolinum, 2001. 425 s. Práce z dějin vědy. Studies in the history of sciences and humanities; 2.

Acta Universitatis Carolinae. Historia Universitatis Carolinae Pragensis. Př́rspěvky k dějinám Univerzity Karlovy. Uspořádali Petr Svobodný a Blanka Zilynská, 40, 2000 [vyd. 2001], fasc. 1-2. $142 \mathrm{~s}$.

Acta Universitatis Carolinae. Historia Universitatis Carolinae Pragensis. Př́spěvky k dějinám Univerzity Karlovy. Uspořádali Petr Svobodný a Blanka Zilynská, 41, 2001 [vyd. 2002], fasc. 1-2.254 s.

Acta Universitatis Carolinae. Historia Universitatis Carolinae Pragensis. Př́spěvky k dějinám UniverzityKarlovy. Uspořádali Petr Svobodný a Blanka Zilynská, 42, 2002 [vyd. 2003], fasc. 1-2.217 s.

Acta Universitatis Carolinae. Historia Universitatis Carolinae Pragensis. Př́spěvky k dějinám Univerzity Karlovy. Uspořádal Petr Svobodný, 36-38, 1996-1998 [vyd. 2004], fasc. $1-2.93 \mathrm{~s}$.

Acta Universitatis Carolinae. Historia Universitatis Carolinae Pragensis. Př́spěvky k dějinám Univerzity Karlovy. Uspořádali Petr Svobodný a Blanka Zilynská, 43, 2003 [vyd. 2004], fasc. 1-2. $307 \mathrm{~s}$.

České zdravotnictví: vize a skutečnost: složité peripetie od plánů k realizaci. Editoři. Hana Mášová, Eva Kř́̌žová, Petr Svobodný. Praha: Karolinum, 2005. 250 s. ISBN 80-246-0944-4.

Historia - Medicina - Cultura. Sbornik k dějinám mediciny. Karel Černý, Petr Svobodný (editoři). Praha: Karolinum, 2006. 289 s. ISBN 80-246-1099-X.

Acta Universitatis Carolinae. Historia Universitatis Carolinae Pragensis. Př́spěvky k dějinám Univerzity Karlovy. Uspořádali Petr Svobodný, Blanka Zilynská, Kateřina Schwabiková. 44, 2004 [vyd. 2006], fasc. 1-2. 270 s.

Bibliografii zpracovala Jiřina Urbanová 